\title{
Seasonal Changes in the Susceptibility of Japanese Pear (Pyrus serotina Rehd.) cv. "Kosui" Fruit to the Japanese Pear Scab Fungus, Venturia nashicola*
}

\author{
Seisaku UMEMOTO**,
}

\begin{abstract}
The effects of the fruit growth stage on the susceptibility to and the latent period of scab fungus on Japanese pear cv. "Kosui" were investigated. The degree of fruit susceptibility to the scab disease was high from the fruit receptacle stage (before bloom) to the young fruit stage (about 2 weeks after bloom). Susceptibility to the disease quickly decreased from mid May (about 25 days after bloom) and was low until early June (about 50 days after bloom) then gradually increased again. Susceptibility reached its highest during early to mid July (about 75 to 90 days after bloom). The latent period of the disease was short, 14 to 21 days, during the stage of high susceptibility and long, about one month, during the stage of low susceptibility. The percentage of cracked fruits was highest in fruits inoculated during early to late May (about 15 to 30 days after bloom), and was little lower during mid June. From the standpoint of orchard management, fruit cracking caused by fungus infection during early May and mid to late June is practically important because of high fruit susceptibility to the disease. This indicates that the best time for controlling the disease on fruit of cv. "Kosui" with fungicides in the Kanto district is from prebloom to early May and again from mid June to mid July (about 55 to 90 days after bloom). The results obtained from this work may be revised for an earlier calendar timing to be adapted in the Kyushu district, warmer area in Japan, and for a later calendar timing to be adapted in the Tohoku district, cooler area.
\end{abstract}

(Received July 11, 1990)

Key words : Venturia nashicola, Japanese pear cv. "Kosui”, fruit susceptibility, latent period, cracking of fruit.

\section{INTRODUCTION}

The major cultivars of Japanese pear (Pyrus serotina Rehd.) in Chiba Prefecture are "Kosui", "Hosui", "Chojuro" and "Niitaka". With the exception of "Niitaka", which is usually bagged in late June or early July, these cultivars are generally cultivated without bagging the fruit. Only "Kosui" is very susceptible to Japanese pear scab caused by Venturia nashicola during the later stage of fruit growth, which occurs after mid June (about 55 days after bloom). This occasionally causes problems to orchard disease management due to reductions in yield and quality.

The susceptibility of old pear cultivars, such as "Shinchu", "Taihaku" and "Waseaka" to Japanese pear scab has been described, but development of the disease on various parts of the tree was not determined ${ }^{1-6)}$. Susceptibility of fruit among the modern pear cultivars, such as "Kosui" and "Hosui",

* Abstract of this study was represented in the 5th International Congress of Plant Pathology at Kyoto in Japan (1988).

** Chiba Prefectural Agricultural Experiment Station, 808 Daizenno-cho, Chiba 280-01, Japan千葉県農業 試験場

+ Present address : Division of Agricultural Technology, Department of Agriculture and Forestry of Chiba Prefecture, 1-1 Ichiba-cho, Chiba 260-91, Japan＼cjkstart現在：千葉県庁農業改良課専技室 
to $V$. nashicola has not been described. A better understanding of the development of the disease on fruit, especially on cv. "Kosui", is necessary to establish more effective control measures for the disease.

In this study, seasonal changes in the susceptibility of "Kosui" fruit to Japanese pear scab and the latent period of the disease were investigated. The information should help to establish effective control measures for the disease.

\title{
MATERIALS AND METHODS
}

Inoculum source. For the inoculation of fruit receptacles and young fruits on potted cv. "Kosui" trees, conidia from natural lesions on scales and the basal parts of the axillary buds were suspended in distilled water containing $0.01 \%$ spreader (to prevent clumping of conidia) and $1 \%$ sucrose (to stimulate conidial germination). The concentration of conidia was determined with a hemacytomater and adjusted to $0.5-1.0 \times 10^{5} / \mathrm{ml}$. For the inoculation of fruits on adult trees, conidia from lesions on natural diseased leaves and young fruits on cv. "Chojuro" trees were suspended in water containing the same concentration of spreader and sucrose described above. The concentration of conidia was adjusted to about $2.5 \times 10^{5} / \mathrm{ml}$ (only in 1977) or $1.0 \times 10^{5} / \mathrm{ml}$.

Inoculation. Potted "Kosui" trees with receptacle clusters or fruit clusters were inoculated before bloom to about 3 weeks after bloom in 1985, 1986 and 1987. Fruits of adult cv. "Kosui" trees (12-year-old in 1984) were inoculated from early May (about 15 days after bloom). Small paper bags, normally used to protect young fruit of cv. "Nijisseiki" from black spot caused by Alternaria alternata Japanese pear pathotype, were used to protect young fruits of cv. "Kosui" from pear scab infection. Fruits used for late inoculations (from about 55 days after bloom) were bagged again with a larger paper bag before the small bag burst from fruit enlargement. These experiments were conducted over a period of 5 years $(1977,1980,1985,1986$ and 1987). In each year, 20 to 30 fruits per plot were evaluated. The cultivars "Kosui", "Hosui", "Chojuro" and "Niitaka" were compared for susceptibility to the disease from early June to late July in 1987, by inoculating fruits on adult trees as described above.

Clusters of receptacles or young fruits on potted trees were inoculated with conidial suspension to the point of run-off, using a chromatograph sprayer. Fruits on adult trees were inoculated to the point of run-off, using a hand sprayer. Inoculations were carried out about every 10 days.

Method of maintaining humidity. Inoculated trees were kept in a dew chamber at $20^{\circ} \mathrm{C}$ for $48 \mathrm{hr}$ with fluorescent lighting $(20 \mathrm{~W})$ after inoculation, then transferred to the northern side of a building where there was limited solar radiation, and the inoculum source of the disease was absent. Fruits on adult trees were bagged just after inoculation.

Observation of disease development. The trees were observed every few days from just before to immediately after the initial occurrence of the disease. Development of the disease on young fruit on potted trees was assessed from the percentage of diseased area ratio (diseased area/whole area of individual fruit). Development of the disease on fruits on adult trees was determined by counting the number of lesions per fruits.

Percentage of cracked fruit. The percentage of cracked fruits caused by scab disease was determined by the number of diseased and cracked fruits divided by the number of observed fruits multiplied by 100 .

Fruit growth stage. The fruit growth stage is expressed by the number of days after full bloom of cv. "Kosui". To pinpoint the fruit growth stage, the average date of full bloom was defined as April 20 during each of the 5 years of this study. The biggest difference of days from the average day (April 20) to full bloom was 6 days in 1987 (April 14) and the smallest difference of days was 1 day in 1985 (April 21).

\section{RESULTS}

\author{
Relationship between time of inoculation and type of lesion
}

Fruit inoculated with $V$. nashicola during the period from before bloom to about 2 weeks after 


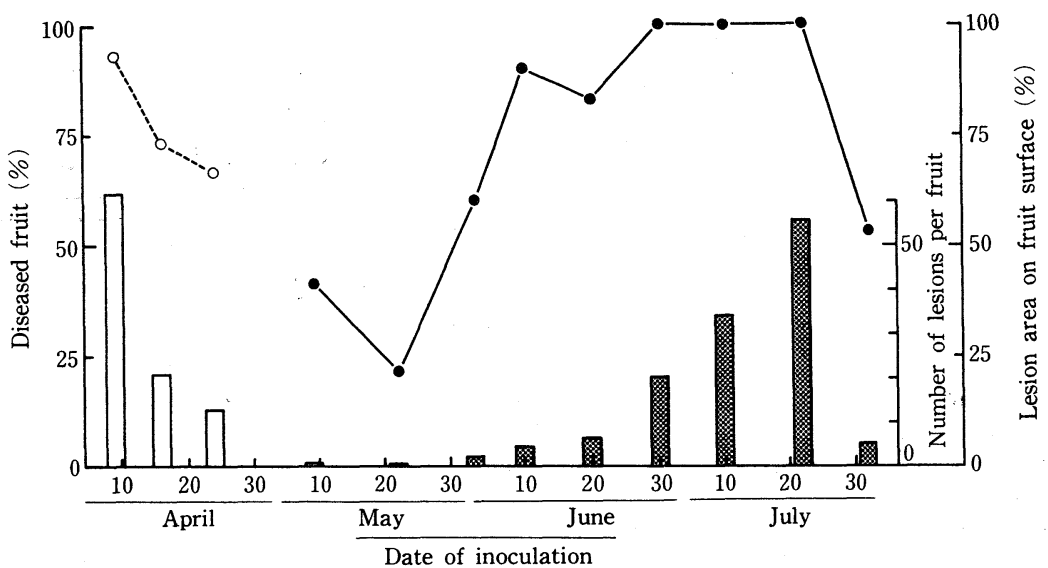

Fig. 1. Susceptibility of fruits of Japanese pear cv. "Kosui" inoculated with $V$. nashicola at different times of the years. $\bigcirc$ : diseased fruit (1987). $\square$ : lesion area on fruit surface (\%). diseased fruit (1986). $:$ number of lesions per fruit.

Table 1. Development of Japanese pear scab on fruits of different cultivars of Japanese pear with different time of artificial inoculation in 1987

\begin{tabular}{|c|c|c|c|c|}
\hline Cultivar & $\begin{array}{c}\text { Date of } \\
\text { inoculation }\end{array}$ & $\begin{array}{l}\text { No. of fruits } \\
\text { tested }\end{array}$ & $\begin{array}{l}\text { Diseased } \\
\text { fruits (\%) }\end{array}$ & $\begin{array}{l}\text { No. of lesions } \\
\overline{\mathrm{x}} \pm \text { S.D. }{ }^{\mathrm{a})}\end{array}$ \\
\hline \multirow{7}{*}{ "Kosui"b) } & June 9 & 28 & 88.9 & $5.6 \pm 5.3$ \\
\hline & 19 & 30 & 86.7 & $23.2 \pm 20.6$ \\
\hline & 29 & 30 & 83.3 & $55.1 \pm 42.9$ \\
\hline & July 8 & 29 & 79.3 & $13.6 \pm 15.6$ \\
\hline & 17 & 29 & 48.3 & $2.9 \pm 6.4$ \\
\hline & 29 & 29 & 3.3 & $0 \pm 0.2$ \\
\hline & None & 28 & 3.6 & $0.1 \pm 0.4$ \\
\hline \multirow[t]{7}{*}{ "Hosui" } & June 9 & 25 & 8.0 & $0.2 \pm 0.8$ \\
\hline & 19 & 28 & 25.0 & $0.8 \pm 2.1$ \\
\hline & 29 & 26 & 38.5 & $0.5 \pm 0.8$ \\
\hline & July 8 & 24 & 4.2 & $0 \pm 0.2$ \\
\hline & 17 & 29 & 3.4 & $0.1 \pm 0.6$ \\
\hline & 29 & 30 & 0 & - \\
\hline & None & 30 & 0 & - \\
\hline \multirow[t]{7}{*}{ "Chojuro" } & June 9 & 20 & 50.5 & $2.6 \pm 4.0$ \\
\hline & 19 & 19 & 5.3 & $0.1 \pm 0.2$ \\
\hline & 29 & 19 & 0 & - \\
\hline & July 8 & 20 & 0 & $=-$ \\
\hline & 17 & 19 & 0 & - \\
\hline & 29 & 19 & 0 & - \\
\hline & None & 20 & 5.0 & $0.1 \pm 0.2$ \\
\hline \multirow[t]{7}{*}{ "Niitaka" } & June 9 & 10 & 80.0 & $4.4 \pm 3.7$ \\
\hline & 19 & 10 & 0 & - \\
\hline & 29 & 10 & 0 & - \\
\hline & July 8 & 10 & 100.0 & $6.5 \pm 4.9$ \\
\hline & 17 & 10 & 90.0 & $6.5 \pm 6.6$ \\
\hline & 29 & 10 & 0 & - \\
\hline & None & 20 & 0 & - \\
\hline
\end{tabular}

a) Standard deviation.

b) The date of full bloom of cv. "Kosui" was April 14, 1987. 
bloom produced lesions which spread over the surface of fruit and became large (Plate I-1). In contrast, the lesions on the fruit inoculated about 3 weeks or more after bloom did not spread and were randomly scattered on the surface of the fruit (Plate I-2).

\section{Relationship between time of inoculation and susceptibility of fruit}

Since the type of lesion differed with the time of inoculation, it was difficult to relate the susceptibility of fruit to Japanese pear scab with the stage of fruit growth. Judging from the percentage of diseased area per young fruit (about 10 days before through about 2 weeks after bloom), or the number of the lesions per fruit at a later stage in fruit growth (about 3 weeks after bloom to just before harvest), the susceptibility of fruit was very high during the period before bloom to about 2 weeks after bloom. It then decreased quickly and remained for one month before gradually increased again from mid June (about 55 days after bloom). The highest level of disease occurred in early to mid July (about 75 to 90 days after bloom) (Fig. 1). Figure 1, obtained from results of 1986 and 1987, shows the typical pattern of the seasonal changes of fruit susceptibility to $V$. nashicola among experiments for 3 years with potted trees and experiments for 5 years with adult trees. An exception to this occurred in 1987 when susceptibility was highest at the end of June (76 days after bloom) and then quickly decreased (Table 1).

\section{Differences in susceptibility of fruit among the major cultivars to V. nashicola}

Only cv. "Kosui" fruit showed increasing susceptibility, judging from number of lesions, to Japanese pear scab from mid June (56 days after bloom), reaching the highest levels at the end of June (76 days after bloom) in 1987 (Table 1). The susceptibility of other cultivars remained low.

\section{Inoculation time and the disease latent period on fruit}

The latent period of the disease was 14 to 18 days on fruit inoculated from about 10 days before

Table 2. Days of the shortest latent period with different times of inoculation to cv. "Kosui" fruits

\begin{tabular}{|c|c|c|}
\hline \multicolumn{2}{|c|}{ Date of inoculation } & \multirow{2}{*}{$\begin{array}{c}\text { The shortest latent period } \\
\\
18\end{array}$} \\
\hline April & 9 & \\
\hline & 16 & 14 \\
\hline & 24 & 15 \\
\hline & 30 & 14 \\
\hline \multirow[t]{8}{*}{ May } & 1 & 14 \\
\hline & 6 & 16 \\
\hline & 8 & 21 \\
\hline & 9 & 21 \\
\hline & 11 & 22 \\
\hline & 19 & 27 \\
\hline & 23 & 36 \\
\hline & 29 & 26 \\
\hline \multirow[t]{10}{*}{ June } & 2 & 24 \\
\hline & 4 & 27 \\
\hline & 9 & 28 \\
\hline & 10 & 29 \\
\hline & 11 & 29 \\
\hline & 17 & 28 \\
\hline & 19 & 24 \\
\hline & 20 & 24 \\
\hline & 29 & 15 \\
\hline & 30 & 21 \\
\hline \multirow[t]{4}{*}{ July } & $8 \ldots \ldots \ldots$ & 14 \\
\hline & $9 \cdots$ & 16 \\
\hline & $17 \quad \ldots$ & 21 \\
\hline & 21 कानि: & 17 \\
\hline
\end{tabular}

a) The shortest latent period is determined from experimental results of $-1980,1985,1986$ and 1987. 
bloom to 2 weeks after bloom, 22 to 36 days on fruit inoculated from mid May to mid June (about 25 to 55 days after bloom), and 14 to 21 days on fruit inoculated after late June (Table 2).

\section{Incidence of fruit lesions}

The total number of lesions increased with time. The increasing number of lesions per day on fruit inoculated -on July 9, 1980, when susceptibility was thought to be highest, were plotted as a single peak, and the number of lesions were plotted out as a sigmoid curve (Fig. 2). The results of the other inoculation tests were almost identical to that of illustrated in Fig. 2.

\section{Fruit cracking based on inoculation time}

$\mathrm{Cv}$. "Kosui" fruit tended to crack during early to mid July (about 75 to 90 days after bloom) at site of fungal infection (Plate I-3). The percentage of cracked fruits inoculated at different times was highest at early to late May (about 15 to 30 days after bloom), low at early June (about 45 days after bloom), moderately high at mid June and lowest at mid to late July (Fig. 3).

\section{DISCUSSION}

The latent period of Japanese pear scab on cv. "Kosui" fruit is highly correlated with the degree of susceptibility (Fig. 1 and Table 2). Namely, susceptibility was very high and the period was short (14

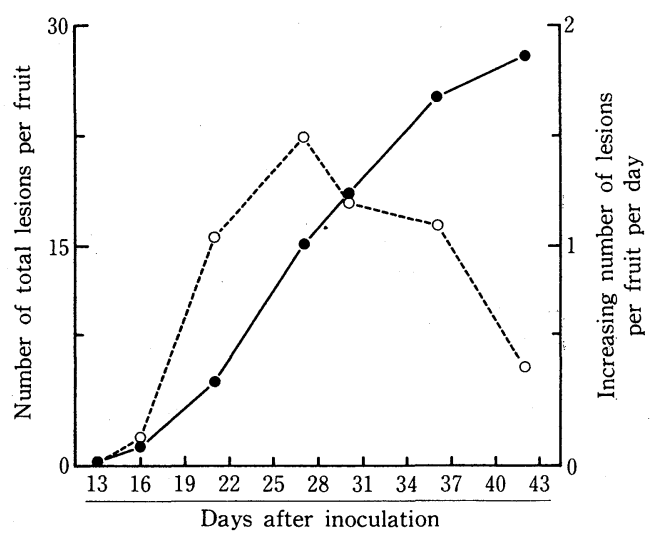

Fig. 2. Changes in the numbers of lesions of scab on fruit of Japanese pear cv. "Kosui" inoculated on July $9,1980$.

- : number of total lesions, $\bigcirc$ : increasing number of lesions per fruit.

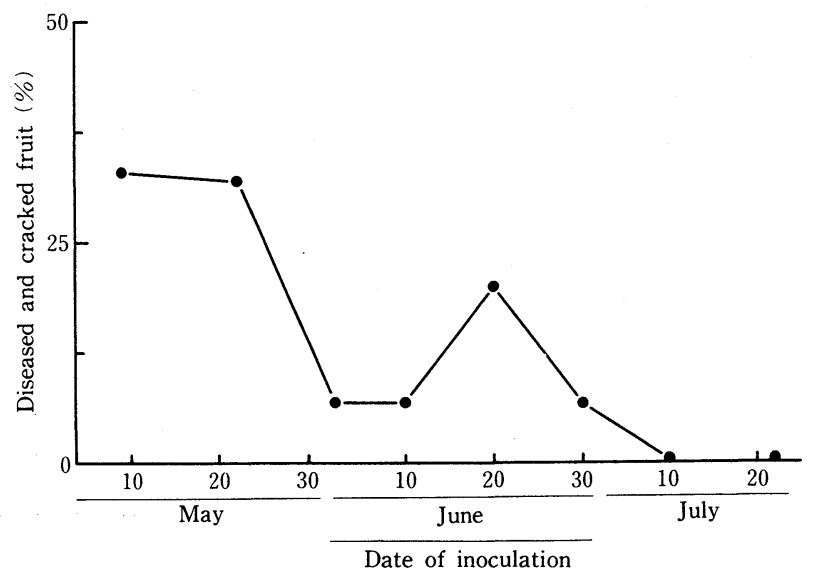

Fig. 3. Diseased and cracked fruit of Japanese pear cv. "Kosui" caused by inoculations of V. nashicola at different time in 1986. 
to 18 days) for the early stage of fruit growth and somewhat longer (14 to 21 days) in late June to mid July ( 65 to 90 days after bloom). On the other hand, susceptibility was very low and the period was long (24 to 36 days) in mid May to mid June. This information can be used to predict the time of prevalence of the disease and to calculate the best times for combating the fungus with fungicides.

Fruit of cv. "Kosui" infected with $V$. nashicola in early to late May (about 15 to 30 days after bloom) and in mid June readily cracked (Fig. 3). Since the susceptibility of fruit to Japanese pear scab decline rapidly from mid May to early June, cracking of infected fruit was not severe under orchard conditions at this time. On the other hand, susceptibility of the fruit was gradually increased from mid June to mid July (about 55 to 90 days after bloom). Fruit of cv. "Kosui" tended to crack in early to mid July. Shortest latent period of the disease on fruit breaking out during this period was 14 to 28 days. It is clear that cracking of fruit infected in early May and mid to late June is very serious (Fig. 3).

Because the shape of fruit was not typically spherical or ellipsoidal, the fruit surface area at time of inoculation could not be calculated in these experiments. However, lesions on fruit inoculated at before and within 2 weeks after bloom were getting so large that the fruit surface area at time of inoculation need not be considered as a factor in determinating susceptibility. On the other hand, fruit surface area in inoculation at the later growth stage may directly relate to the number of lesions because the lesions were independent each other. If fruit susceptibility to the disease is assumed to be the same in later growth stages, the number of lesions on a fruit may be less on small fruit than large one. Therefore, the actual fruit susceptibility at the later stage of fruit growth may be lower than shown in Fig. 1. However, the pattern of susceptibility with fruit growing illustrated in Fig. 1 may not change.

It is determined that only cv. "Kosui" fruit is highly susceptible to Japanese pear scab among the major cultivars in the later stage of fruit growth (about 55 days after bloom). One of the major reasons for the high level of fruit susceptibility of this cultivar at this stage was considered to be the poor development of the corky layer in fruit surface compared with other cultivars ${ }^{7}$.

The reason that the inoculation experiments indicated a low fruit susceptibility after mid July might be because high temperature suppressed fungal growth and there was too short of a period from inoculation to harvest. These are external factors that decrease fruit susceptibility. Actual fruit susceptibility at this time might be not low as indicated in Fig. 1 by the fact that the lesions increased on the fruit at the later half of harvest season (about 120 days after bloom) in years of many rainy days during late July to early August and delay in harvest.

The reason that the day of full bloom of cv. "Kosui" was defined as April 20 was that there was only a small difference among individual full bloom days in all 5 years and the difference of growth stage got smaller with passage of days after bloom. Additionally, it is very complicated to show every year's results with 10 day intervals for a month or days after its full bloom.

The results obtained in the experiments can be adapted to pear scab control of cv. "Kosui" in Kanto district but may need to be revised for an earlier calendar timing to be adapted to the cultivar in the Kyushu district, warmer area in Japan, and for a later calendar timing to be adapted to the cultivar in the Tohoku district, cooler area.

The author thanks Dr. H. Tanaka, Fruit Tree Research Station (former), for critically reading the manuscript and for his valuable suggestions and Dr. M. Grindle of Sheffield University for critically reading the manuscript.

\section{Literature cited}

1. Bokura, U. (1934). Japanese pear scab and its control. Byochuzasshi (Disease and applied entomology) $21: 419-422$ (in Japanese).

2. Ikata, S. and Kotani, T. (1940). The nature of Japanese pear scab fungus and control of the disease. Nogyo oyobi Engei 15 : 133-144 (in Japanese).

3. Misonou, T. and Fukatsu, R. (1973). Studies on the infection and control of pear scab. 5. The perfect stage of the pathogen on the fallen leaves and effect of some fungicides on it. Bull. Chiba Agric. Exp. Stn. 13 : 9- 21 (in Japanese).

4. Nishi, T. (1909). Bordeaux mixture as fungicide for Japanese pear scab control. Nippon Engeigaku Zasshi 


\section{Plate I}
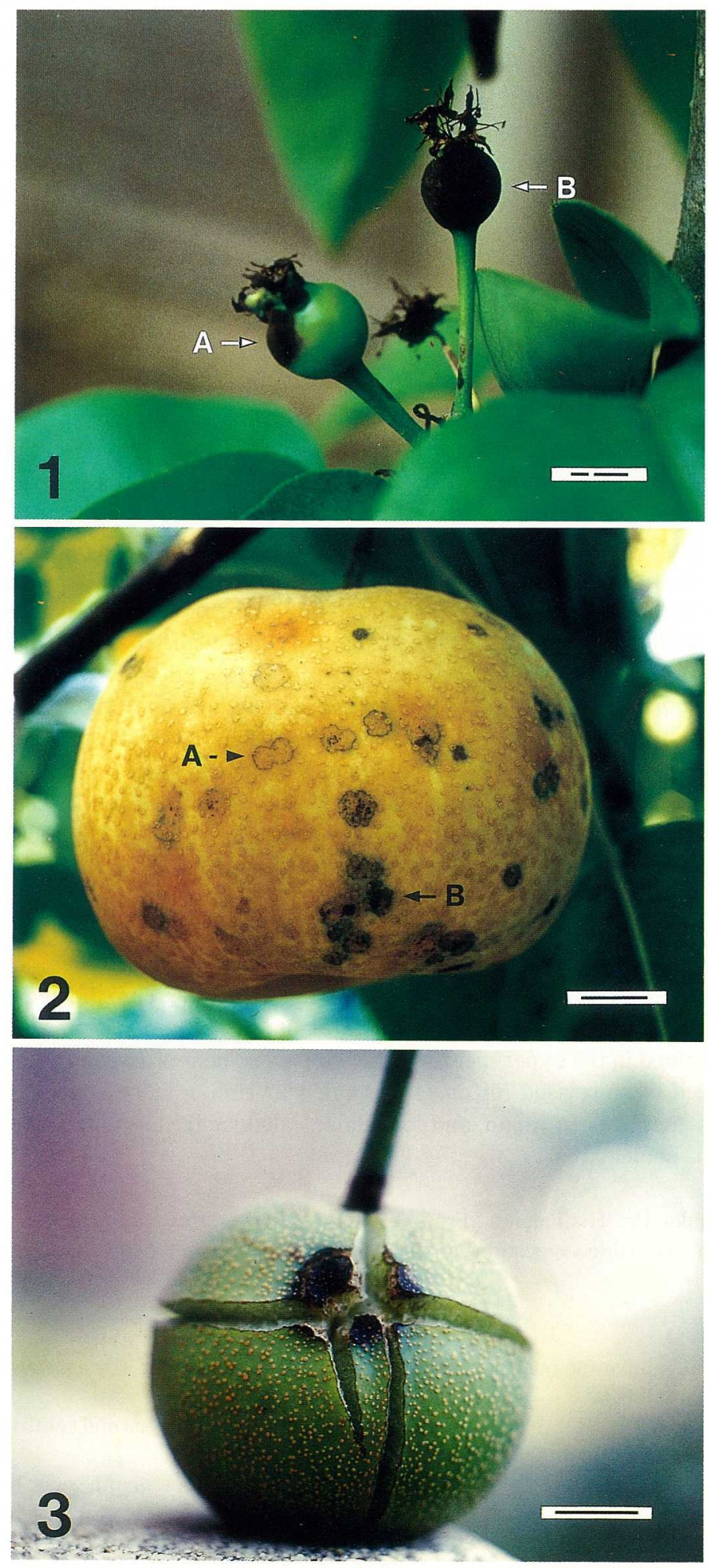
21: $36-46$ (in Japanese).

5. Okumura, K. (1907). Study on the Japanese pear scab. Morioka Nougei Kaiho 1: 1-19 (in Japanese).

6. Takahashi, Y. (1903). Japanese pear scab. Re. Hokkaido Nat. Agric. Exp. Stn. 1: 105-111 (in Japanese).

7. Takamura, N. (1990). Method of promotion to make corky tissue on the surface of fruit, Japanese pear "Kousui", by using the adjuvant when spraying pear trees. Tohoku Agric. Res. 43 : 113-114 (in Japanese).

\section{和 文 摘 要}

\section{梅本清作：ニホンナシ“幸水”果実の黒星病に対する感受性の推移}

ニホンナシ “幸水”果実の黑星病に対する感受性と潜伏期間の推移について, 接種試験で検討した。果実の黒星病に 対する感受性の程度を幼果期には病斑面積率, それ以降は果実当たりの病斑数で判定したところ, 開花前から 5 月上旬 の幼果期には高く, 5 月中旬頃（開花約 25 日後）から急激に低下した。6 月中旬（開花約 55 日後）から再び徐々に高 まり, 肥大後期では通常 7 月上旬または中旬に最も感受性が高まった。また, 潜伏期間は果実の黒星病に対する感受性 が高いと判定される時期においては 14〜21 日と短く, 低いと判定される時期では約 1 力月を要した。一方, 果実の裂 果率は接種時期によって異なり, 5 月上旬〜下旬接種で最も高く, ついで 6 月中旬で, その他の時期は低かった。この うち, 5 月中旬 6 月上旬までの果実の感受性は低いことから, 栽培上は 5 月上旬と 6 月中〜下旬頃の感染による裂果 が問題視される。以上の結果から, 千葉県の “幸水”果実において黒星病に対する防除が特に重要となる時期は 5 月上 旬までの幼果期および 6 月中旬〜 7 月中旬 (開花約 55〜90 白後) であることを明らかにした。なお, この結果を関東地 方においては直接適用できるが, 西南暖地ではここに示した暦日より早く, 東北地方では遅くなるように修正する必要 がある。

\section{Explanation of plate}

\section{Plate I}

1. Lesions of Japanese pear scab on young fruit of cv. "Kosui" inoculated on April 16, 1987. (Photographed on May 7. Scale bar represents $1 \mathrm{~cm}$ ).

A : Lesion produced.

B : Lesion spreading all over the surface of young fruit.

2. Independent lesions of Japanese pear scab on fruit of cv. "Kosui" inoculated on July 10, 1986. (Photographed on August 25. Scale bar represents $1 \mathrm{~cm}$ ).

A : Early stage of pear scab lesion on mature fruit.

B : Middle or late stage of pear scab lesion on mature fruit. Lesions not spreading over the surface of fruit.

3. The fruit cracking at site of natural infection by V. nashicola. (Photographed on July 6, 1983. Scale bar represents $1 \mathrm{~cm}$ ). 